\title{
Hemşirelik Bölümü Son Sınıf Öğrencilerinin Bireysel Kariyer Planlama Eğilimlerinin Değerlendirilmesi
}

\author{
Hava GÖKDERE ÇINAR ${ }^{1}$, Dilek YILMAZ ${ }^{2}$, Burcu ARKAN ${ }^{3}$, Melik ARSLAN $^{4}$ \\ 1 Bursa Uludağ Üniversitesi, Sağlık Bilimleri Fakültesi, Hemşirelikte Yönetim Anabilim Dalı, Bursa. \\ 2 Bursa Uludağ Üniversitesi, Sağlık Bilimleri Fakültesi, Hemşirelik Esasları Anabilim Dalı, Bursa. \\ 3 Bursa Uludağ Üniversitesi, Sağlık Bilimleri Fakültesi, Psikiyatri Hemşireliği Anabilim Dalı, Bursa. \\ 4 Bursa Uludağ Üniversitesi, Sağlık Bilimleri Fakültesi, 4. Sınıf Öğrencisi, Bursa.
}

\section{ÖZET}

$\mathrm{Bu}$ araştırma hemşirelik son sınıf (4. Sınıf) öğrencilerinin bireysel kariyer planlama eğilimlerinin değerlendirilmesi amaçlanmıştır. Araştırma, 2018-2019 Eğitim-Öğretim yılında Bursa Uludağ Üniversitesi Sağlık Bilimleri Fakültesi Hemşirelik Bölümü 4. sınıf öğrenciler üzerinde yürütülmüştür. Veri toplama aracı olarak "Öğrenci Tanıtım Formu" ve "Kariyer Geleceği Ölçeği (KARGEL)" kullanılmıştır. Çalışmaya katılmayı kabul eden 83 öğrencinin yaş ortalaması $22,14 \pm 1,48$ ve \%63,9'u kadındır. Hemşirelik mesleğini tercih etme nedenlerinden en fazla tercih edilen \%38,6 ile iş bulma imkânı kolaylığıdır. Öğrencilerin cinsiyetine ve "Bölümü isteyerek seçme durumu", "Mesleği sevme durumu", "Kariyer firsatların bilme durumu", "Hemşirelik mesleğini tercih etme nedeni" ve "Kariyer planı hedefleri” sorularına verdikleri yanıtlara göre KARGEL alt boyut ölçek puanları açısından istatistiksel olarak anlamlı bir fark bulunamamıştır. Araştırma sonuçlarına göre öğrencilerinin Kariyer Geleceği Ölçeği toplam puan ortalamaları yüksek düzeydedir $(85,36 \pm 12,62)$. Öğrencilerin mevcut kariyer iyimserliği, kariyer uyumunun ve bilgi alt boyutlarının öğrencilerde yüksek olması nedeni ile bu sonucu öğrencilerde firsata dönüştürülebilmesi için kariyer danışmanlığı sürecinin eğitim kurumlarınca daha iyi yönetilmesinin önemli olduğu düşünülmektedir.

Anahtar Kelimeler: Kariyer. Kariyer Planlama. Kariyer Geleceği. Algılanan Kariyer Engelleri. Hemşirelik Öğrencileri.

Evaluation of Individual Career Planning Trends of Final-Year Nursing Students

\begin{abstract}
This study aimed to evaluate the individual career planning trends of final-year nursing students. The study was conducted with final-year nursing students (4th grade) in the Faculty of Health Sciences, Bursa Uludağ University, Turkey in the 2018-2019 academic year. "Student Introduction Form" and "Career Future Invenotry (CFI)" were used as data collection tools. The mean age of 83 students who agreed to participate in the study was $22.14 \pm 1.48$ and $63.9 \%$ of them were women. The most preferred reason for choosing the nursing profession is the ease of finding a job with $38.6 \%$. There wasn't a statistically significant difference in terms of KARGEL sub-dimension scale scores according to the gender of the students and their answers to the questions "Choosing the department willingly", "Loving the profession", "Knowing career opportunities", "Reason for choosing the nursing profession" and "Career plan goals" was found. According to the results of the research, the total mean score of the Career Future Inventory of the students is high (85.36 12.62$)$. Since students' current career optimism, career adaptability and knowledge sub-dimensions are high in students, it is thought that it is important to better manage the career counseling process by educational institutions in order to turn this result into an opportunity for students.
\end{abstract}

Key Words: Career. Career Planning. Career Future. Perceived Career Barriers. Nursing Students.

Geliş Tarihi: 11.Kasım.2021

Kabul Tarihi: 03.Aralık.2021

* Bu araştırma 18. Ulusal Hemşirelik Öğrencileri Kongresi'nde (25-27 Nisan 2019, Afyon/Türkiye) sözlü bildiri olarak sunulmuş ve kongre özet kitabında yayınlanmıştır.

Dr. Hava GÖKDERE ÇINAR

Bursa Uludağ Üniversitesi,

Sağlık Bilimleri Fakültesi,

Hemşirelikte Yönetim Anabilim Dalı, Bursa.

Tel: 050549900 90/0224 2942459

E-posta: havagokdere@uludag.edu.tr

Yazarların ORCID Bilgileri:

Hava GÖKDERE ÇiNAR: 0000-0002-5792-5958

Dilek YILMAZ: 0000-0001-7269-8493

Burcu ARKAN: 0000-0002-7285-6196

Melik ARSLAN: 0000-0002-2273-3825
"Kariyer" kavramı, Türk Dil Kurumu tarafından 2019 yılında bir meslekte zaman içinde ve çalışırken ilerlemek, hedeflere ulaşmak ve uzmanlık kazanmak olarak tanımlanmıştır. Kariyer sahibi olmak" genellikle bir meslek alanında ilerlemek, belirli bir statü kazanmak ve arzu edilen meslekte çalışmak olarak kabul edilir. Özetle kariyer sahibi olmak, profesyonel bir alanda ilerlemek ve belirli bir statü kazanmak olarak düşünülebilir. ${ }^{1}$ Kariyeri, çalışma hayatında kademeli ve aşamalı olarak beceri ve deneyim kazanma süreci olarak da tanımlamak mümkündür. ${ }^{2}$ Diğer bir ifadeyle, kariyer sahibi olmak ilerlemek demektir. ${ }^{3}$

"Kariyer Planlaması", çalışanların kariyerlerinde ilerleme ve statü kazanma eğitimleri, entelektüel yetenek- 


\section{H. Gökdere Çinar, ark.}

leri ve kişiliklerini geliştirme istekleri ile yakından ilgilidir. Kariyer planlaması, çalışanların mesleki yaşamlarında ilerlemelerine yardımcı olabilir. En basit tanımıla kariyer planlaması, bireylerin mesleki yaşamları ile ilgili yaptıkları planlardır. ${ }^{4}$ Kariyer planlaması ve yönetimi, bir mesleği ve bireylerin bir mesleğe yönelik kişisel tutum ve davranışlarını anlamada önemli kavramlar haline gelmiştir. ${ }^{3}$ Kariyer planlamasının temeli bireylerin becerilerini geliştirmektir. Kariyer planlaması bu nedenle kendini geliştirme ile yakından ilişkilidir. Temel olarak bireylerin var olan özelliklerinden başlayıp mevcut becerilere yeni beceriler ekleyerek onları geliştiren bir süreçtir. Bu bağlamda, kariyer planlaması çok zorlu ve uzun bir süreç olabilir. ${ }^{5}$ Her insan erken yaşta geleceği hayal etmeye başlar ve kendisine hangi mesleklerin uygun olacağını düşünür. Bu hayaller, bireyin meslek seçimini, fırsatları nasıl değerlendirdiğini ve sonraki dönemlerde rakiplerinden sıyrılma çabasını şekillendirir. ${ }^{3,5}$

Mezun olduktan sonra iş bulabilmek, çalışılacak alanla ilgili becerileri geliştirebilmek ve meslek hayatına daha kolay uyum sağlayabilmek için eğitim döneminde kariyer planlamasına başlamak çok önemlidir. Öğrencilerin genellikle mezun olduktan sonra kariyerlerini düşünmeye başlamaları, eğitimleri boyunca bu konuda yeterli farkındalığa sahip olmadıklarını göstermektedir. Üniversite yılları, öğrencilerin kariyerlerini keşfetmeleri gereken önemli bir dönemdir. $\mathrm{Bu}$ aşamada onları doğru seçimler yapmaya yönlendirmek son derece önemlidir. Aksi takdirde öğrenciler bir mesleğe giriş yapmanın en iyi yolunu planlayamazlar; bu durum kariyer hedeflerine ulaşmaya çalışırken zaman ve kaynak israfına yol açmaktadır. ${ }^{6}$

Bireyin kariyer hedeflerine ulaşmasını engelleyen unsurlara kariyer engelleri denir. ${ }^{7}$ Kariyer engellerinin başında bireylerin kariyer geleceklerine ilişkin amaçlarını belirleyememiş olmaları gelmektedir. Amaçların net bir şekilde belirlenemediği bu dönemde çoğu zaman hızla lisansüstü eğitime başlamayı bir yol olarak çok da irdelemeden seçebilmektedirler. Kariyer beklentilerini geliştirmek için ek eğitime odaklanmak finansal sorunlara neden olabilmektedir. ${ }^{8,9}$

Son araştırmalar, özellikle üniversite öğrencileriyle yapılanlar olmak üzere, bazı dikkate değer sonuçlar sağlamıştır. Örneğin, öğrenciler kariyer planlama konusunda kararsız kalabilmekte ve kendi alanlarındaki işler yerine başka sektörlerdeki istihdam seçeneklerine bakabilmektedir. ${ }^{7-10}$ Öğrenciler kariyer planlaması konusunda yeterince desteklenmemekte, mesleklerini çoğunlukla cinsiyetlerine ve mesleklerine göre seçmektedir. $\mathrm{Bu}$ nedenle üniversitelerin, öğrencileri çalışma hayatına daha iyi hazırlamak için geleneksel sonuçlara odaklanmayan öğrenci merkezli tavsiyeler vermesine ihtiyaç vardır. $\mathrm{Bu}$ bağlamda üniversite öğrencileri kariyerlerini öğrenci merkezli kurumlarla çalışarak planlamalıdır. ${ }^{2}$
Sağllk sektöründe yol alan öğrencilerin kariyer planlaması ele alındığında ise hastanelerde işgücünün büyük bir kısmının hemşirelerce karşılandığ1 gerçeği karşımıza çıkmaktadır. Sağlık kurumları, özellikle alandaki gelişmeler ve sağlık sektöründe değişen ihtiyaçlar nedeniyle çalışanlarının bireysel ve mesleki gelişimlerini sağlayarak nitelikli personel ihtiyacını karşılayabilmektedirler. Kurumların değişen koşullara çerçevesinde hemşirelerin kariyer planlamasını yapmalarının, kurumsal hedeflerin gerçekleștirilmesinde önemli rolleri vardır. ${ }^{5}$ Bazı hemşirelik mezunları, eğitim sürecinde planlananlar ile hemşirelerin çalışma alanlarında yaşadıkları gerçek sorunlar arasında kalarak istihdama geçişte zorluklarla karşı karşıya kalabilirler. $\mathrm{Bu}$ açıdan hemşirelik öğrencilerinin meslekte gelecekteki kariyer planlamasına yardımcı olmak için uygun kariyer stratejileri geliştirmek önemlidir. Çalışmaya hazır olmak, işyerine sorunsuz bir geçiş yapmayı kolaylaştırabileceği gibi, iş tatmini ve işe katılım üzerinde de olumlu etkileri olmaktadır. ${ }^{11}$

Kariyer planlama ve geliştirme, hemşirelerin profesyonel yaklaşımlarına, iş ve özel yaşamlarındaki değişikliklere uyum sağlamalarına yardımcı olmak için gerekli ve önemli bir araçtır. Tüm mesleklerde olduğu gibi hemşirelikte de iş doyumu durağan ve gelişim gösterememiş bir konuma sahip olmaktan olumsuz etkilenir; bu durum hem hemşirelerin hem de toplumun yaşam kalitesini olumsuz etkileyebilmektedir., ${ }^{5,12}$ Neticede henüz öğrencilik döneminde iken öğrenci hemşirelerin kariyer geleceğine olumlu bir bakış açısı içinde olmaları, karşılaştığı sorunlar ile etkili baş etme yöntemleri bulmalarına yardımcı olacaktır. Hemşirelik öğrencilerin eğitim süresince etkin kariyer danışmanlığı, kariyer farkındalığı eğitimleri gibi yönlendirici profesyonel destek alıp alamadıklarının belirlenmesi bireysel kariyer planlama eğilimlerinin değerlendirilmesi ile mümkün olabilir. ${ }^{12} \mathrm{Bu}$ çalışma, hemşirelik son sınıf öğrencilerinin kariyer planlamalarını belirlemek ve mezuniyet sonrası mesleğe geçişlerine destek olmak için bireysel kariyer planlamalarına yönelik eğilimlerini değerlendirmeyi amaçlamaktadır.

\section{Araştırma Sorulart}

Çalışmada:

"Hemşirelik bölümü son sınıf öğrencilerinin bireysel kariyer planlama eğilimleri nelerdir?”,

"Hemşirelik öğrencilerinin kariyer geleceğine yönelik algılarını etkileyen unsurlar nelerdir?" sorularına yanıt aranmıştır.

\section{Gereç ve Yöntem}

$\mathrm{Bu}$ araştırma, kesitsel ve tanımlayıcı bir araştırma olarak yapılmıştır. Araştırma 2018-2019 eğitimöğretim yılında Türkiye'de Bursa Uludağ Üniversitesi Sağlık Bilimleri Fakültesi son sınıf hemşirelik öğren- 


\section{Hemşirelik Öğrencilerinin Kariyer Planlaması}

cileri ile gerçekleştirilmiştir. Araştırmanın evrenini fakültede öğrenim gören ve mezuniyete en yakın grup olan 120 son sınıf hemşirelik bölümü öğrencisi oluşturmuş, çalışmaya gönüllü olarak katılmayı kabul eden 83 öğrenci araştırmanın örneklemi olarak dâhil edilmiştir. Veriler Öğrenci Tanıtım Formu ve Kariyer Gelecekleri Envanteri (KARGEL) kullanılarak toplanmıştır.

\section{Öğrenci Tanıtım Formu}

Araştırmacılar tarafından geliştirilmiş yaş, cinsiyet, mezun olduğu lise, anne ve baba eğitim düzeyi, aile gelir durumu, hemşirelik bölümünü tercih etme nedeni, kariyer planları ve kariyer planlama konusunda engel gördükleri faktörleri belirlemeye yönelik 14 sorudan oluşmuştur.

\section{Kariyer Gelecekleri Envanteri (KARGEL)}

KARGEL, bireylerin kariyer planlamasına yönelik tutumlarını değerlendirmek amaciyla Rottinghaus, Day ve Borgen (2005) tarafından geliştirilmiş ve Kalafat (2012) tarafindan Türkçeye uyarlanmıştır. ${ }^{13}$ Ölçek, kariyer uyumluluğu (KU) 11 madde (1-11. maddeler), kariyer iyimserliği (KI) 11 madde (12-22. maddeler) ve iş piyasalarına ilişkin algılanan bilgi (AB) 3 madde (23-25. maddeler) olmak üzere üç alt boyuttan ve toplam 25 maddeden oluşmaktadır. Ölçek 1'den 5'e kadar puanlanan 5'li likert tipi bir ölçektir. Maddelere verilen cevaplar $1=$ Kesinlikle Katılmıyorum, 2=Katılmıyorum, 3=Kararsızım, 4=Katılıyorum, 5=Kesinlikle şeklinde puanlanmaktadır Ölçekte 15 olumlu, 8 olumsuz madde yer almaktadır. Ölçekte yer alan ters maddelerin puanları tersine çevrilerek, bütün maddeler 1-5 arası puanlanmıştır. KU ve Kİ alt boyutlarından alınabilecek en yüksek puan 55 , en düşük puan ise 11, AB alt boyutundan ise en yüksek puan 15, en düşük ise 3 'dür. Ölçeğin Cronbach alfa güvenirlik katsayısı 0,88'dir. Bu çalışmada envanterin toplam Cronbach alfa değeri 0,81 olarak bulunmuştur. p < 0,05 değeri istatistiksel anlamlılık sınırı olarak kabul edilmiştir.

\section{Araştırmanın Etik Yönü}

KARGEL'nin Türkçe geçerlik ve güvenirlik çalışmasını yapan yazardan e-posta yoluyla yazılı izin alınmıştır. Üniversitenin etik kurulundan gerekli etik kurul onayı (Karar no: 2019-03) ve öğrencilerin yazılı bilgilendirilmiş onamları alınmıştır.

\section{Verilerin toplanması}

Veri formları, 2018-2019 Eğitim-Öğretim y1lı ders döneminde dört haftalık süre içinde, ders aralarında birebir araştırmacılar tarafindan her bir katılımcıya 1015 dakikalık süreler verilerek birebir uyguland1.

\section{Verilerin Değerlendirilmesi}

Verilerin istatistiksel analizi, IBM SPSS 23.0 (IBM Corp. Released 2015. IBM SPSS Statistic for Windows, Version 23.0. Armonk, NY: IBM Corp.) kullanılarak yapıldı. Nicel veriler için ortalama \pm standart sapma, medyan(minimum-maksimum), nitel veriler için frekans ve yüzde değerleri kullanıldı. Verilerin normal dağılım gösterip göstermediğini belirlemek için Shapiro-Wilk testi kullanıldı. İki grubun karşılaştırılmasında Mann-Whitney U testi kullanıldı; İkiden fazla grubun karşılaştırılmasında Kruskal Wallis testi kullanıldı. Anlamlılık düzeyi $\mathrm{p}<0,05$ olarak belirlendi.

\section{Bulgular}

Araştırmaya katılan hemşirelik bölümü son sınıf öğrencilerinin yaş ortalaması 22,14 $\pm 1,48, \% 63,9$ 'u kadin, \%47'si Anadolu lisesi mezunu, babalar1nın \%43,4'ü ve annelerinin \%60,2'si ilköğretim mezunuydu. Öğrencilerin babalarının \%30,1'i işçi, annelerinin \%69,9'u ev hanımıydı. Öğrenci hemşirelerin \%63,9'u mesleği isteyerek seçmişti. Öğrencilerin $\% 38,6$ 'sı hemşirelik mesleğini tercih etmelerindeki en önemli nedenin iş bulma kolaylığı olduğunu belirtti. Kariyer planları içerisinde \%26,5'i yüksek lisans yapmayı planladığını belirtirken, \%22,9'u yönetici hemşire olmak ve özel dallarda eğitim almak istediğini belirtmiştir (Tablo I).

Öğrencilerin KARGEL alt ölçek puan ortalamaları incelendiğinde kariyer uyum yeteneği, kariyer iyimserliği, algılanan bilgi puan ortalamalarının sırasıyla $40,52 \pm 7,95,35,84 \pm 6,30$ ve $9,00 \pm 1,96$, toplam ölçek puan ortalamasının $85,36 \pm 12,68$ olduğu sonucuna ulaşıldı (Tablo II).

Öğrencilerin KARGEL alt boyutlarına ve toplam puanlarına ilişkin puan ortalamaları, öğrencilerin tanıtıcı özelliklerine göre karşılaştırıldı (Tablo III). Öğrencilerin KARGEL alt ölçek ve toplam puanları ile cinsiyete göre ve "Bölümü isteyerek seçme durumu", "Mesleği sevme durumu", "Kariyer firsatlarını bilme durumu", "Hemşirelik mesleğini tercih etme nedeni" ve "Kariyer planı hedefleri" arasında istatistiksel olarak anlamlı bir fark bulunmadı (Tablo III). Yalnızca öğrencilerin \%4,8'i yabancı dil eğitimi almış olmay1, \%3,6's1 bulundukları üniversitenin imajını, \%3,6's1 ise branşlara özel sertifika alabilmeyi öngördükleri kariyer firsatları olarak ifade ettiler. 


\section{H. Gökdere Çinar, ark.}

Tablo I. Öğrencilerin Tanıtıcı Özelliklerinin Dağılımı

\begin{tabular}{|c|c|c|c|}
\hline \multicolumn{2}{|l|}{ Özellikler } & $\mathrm{n}$ & $\%$ \\
\hline \multicolumn{2}{|c|}{ Yaş (ortalama \pm standart sapma) } & \multicolumn{2}{|c|}{$22,14 \pm 1,48$} \\
\hline \multirow[t]{2}{*}{ Cinsiyet } & Kadın & 53 & 63,9 \\
\hline & Erkek & 30 & 36,1 \\
\hline \multirow[t]{5}{*}{ Mezun olunan lise } & Düz lise & 18 & 21,7 \\
\hline & Anadolu lisesi & 39 & 47 \\
\hline & Anadolu öğretmen lisesi & 10 & 12 \\
\hline & Fen lisesi & 5 & 6 \\
\hline & Diğer & 11 & 13,3 \\
\hline \multirow[t]{5}{*}{ Babanın eğitim durumu } & Okur yazar değil & 0 & 0 \\
\hline & Okur yazar & 7 & 8,4 \\
\hline & ilkokul & 36 & 43,4 \\
\hline & Lise & 26 & 31,3 \\
\hline & Lisans & 14 & 16,9 \\
\hline \multirow[t]{6}{*}{ Babanın mesleğ } & Çalışmıyor & 3 & 3,6 \\
\hline & Memur & 12 & 14,5 \\
\hline & ìş̧̧i & 25 & 30,1 \\
\hline & Emekli & 20 & 24,1 \\
\hline & Serbest Meslek & 17 & 20,5 \\
\hline & Vefat etti & 6 & 7,2 \\
\hline \multirow[t]{5}{*}{ Annenin eğitim durumu } & Okur yazar değil & 2 & 2,4 \\
\hline & Okur yazar & 12 & 14,5 \\
\hline & Ilkokul & 50 & 60,2 \\
\hline & Lise & 15 & 18,1 \\
\hline & Lisans & 4 & 4,8 \\
\hline \multirow[t]{6}{*}{ Annenin mesleği } & Ev hanımı & 58 & 69,9 \\
\hline & Memur & 2 & 2,4 \\
\hline & İşçi & 16 & 19,3 \\
\hline & Emekli & 2 & 2,4 \\
\hline & Serbest Meslek & 3 & 3,6 \\
\hline & Vefat etti & 2 & 2,4 \\
\hline \multicolumn{2}{|c|}{ Ailenin gelir durumu (medyan(minimum-maksimum) } & \multicolumn{2}{|c|}{$3000(1000-8000$} \\
\hline \multirow{4}{*}{$\begin{array}{l}\text { Ailenizin gelir durumu nasıl } \\
\text { düşünüyorsunuz }\end{array}$} & Düşük & 11 & 13,3 \\
\hline & Orta & 58 & 69,9 \\
\hline & Iyi & 11 & 13,3 \\
\hline & Çok iyi & 3 & 3,6 \\
\hline \multirow{2}{*}{$\begin{array}{l}\text { Bölümü isteyerek seçme } \\
\text { durumu }\end{array}$} & Evet & 53 & 63,9 \\
\hline & Hayır & 30 & 36,1 \\
\hline \multirow[t]{3}{*}{ Mesleği sevme durumu } & Evet & 50 & 60,2 \\
\hline & Hayır & 11 & 13,3 \\
\hline & Kararsız & 22 & 26,5 \\
\hline \multirow{6}{*}{$\begin{array}{l}\text { Hemşirelik mesleğini tercih } \\
\text { etme nedeni }\end{array}$} & Aile baskısı & 7 & 8,4 \\
\hline & |̧̇ bulma kolaylığı & 32 & 38,6 \\
\hline & Yüksek gelir beklentisi & 15 & 18,1 \\
\hline & $\begin{array}{l}\text { Üniversite sınavina tekrar } \\
\text { girmemek }\end{array}$ & 9 & 10,8 \\
\hline & $\begin{array}{l}\text { Üniversite giriş puanın } \\
\text { bu bölüme yetmesi }\end{array}$ & 7 & 8,4 \\
\hline & Mesleği sevmek & 13 & 15,7 \\
\hline \multirow[t]{6}{*}{ Kariyer Planı hedefleri } & Yönetici hemşire olmak & 19 & 22,9 \\
\hline & Yüksek lisans yapmak & 22 & 26,5 \\
\hline & Özel dallarda eğitimi almak & 19 & 22,9 \\
\hline & Akademisyen olmak & 12 & 14,5 \\
\hline & Meslek değiştirmek & 6 & 7,2 \\
\hline & Hemşire olarak çalışmak & 5 & 6 \\
\hline
\end{tabular}

Tablo II. KARGEL ölçeği alt boyut ve toplam ortalamalarının dağılımı

\begin{tabular}{|l|c|c|c|c|}
\hline & Ortalama & $\begin{array}{c}\text { Standart } \\
\text { sapma }\end{array}$ & Minimum & Maksimum \\
\hline Kariyer uyum yeteneği & 40,52 & 7,95 & 15 & 75 \\
\hline Kariyer iyimserliği & 35,84 & 6,30 & 14 & 51 \\
\hline Algılanan bilgi & 9,00 & 1,96 & 3 & 13 \\
\hline Toplam & 85,36 & 12,62 & 46 & 118 \\
\hline
\end{tabular}

Tablo III. Öğrencilerin tanıtıcı özelliklerine göre KARGEL ölçek alt boyut ve toplam puanlarının karșılaștırılması

\begin{tabular}{|c|c|c|c|c|c|c|}
\hline & & $n$ & $\mathrm{KU}$ & KI & $A B$ & Toplam \\
\hline \multirow{3}{*}{ Cinsiyet } & Kadın & 53 & $41(15-75)$ & $36(14-51)$ & $9(4-12)$ & $84(51-116)$ \\
\hline & Erkek & 30 & $40,5(16-55)$ & $35(26-50)$ & $10(3-13)$ & $85(46-118)$ \\
\hline & $p$ & & 0,820 & 0,642 & 0,051 & 0,718 \\
\hline \multirow{3}{*}{\begin{tabular}{|l} 
Bölümü \\
isteyerek \\
seçme \\
durumu
\end{tabular}} & Evet & 53 & 40 (15-75) & $35(14-50)$ & $9(3-13)$ & $85(46-118)$ \\
\hline & Hayır & 30 & $42(26-54)$ & $36(26-51)$ & $9(5-13)$ & $85,5(68-114)$ \\
\hline & $p$ & & 0,124 & 0,820 & 0,686 & 0,564 \\
\hline \multirow{4}{*}{$\begin{array}{l}\text { Mesleği } \\
\text { sevme } \\
\text { durumu }\end{array}$} & Evet & 50 & $41(15-75)$ & $36,5(14-51)$ & $9,5(3-13)$ & $87,5(46-118)$ \\
\hline & Hayır & 11 & $41(26-54)$ & $35(30-39)$ & $9(5-13)$ & $84(68-104)$ \\
\hline & Kararsızım & 22 & $40(33-47)$ & $33,5(26-45)$ & $8,5(6-11)$ & $82(75-101)$ \\
\hline & $p$ & & 0,876 & 0,378 & 0,216 & 0,515 \\
\hline \multirow{3}{*}{\begin{tabular}{|l} 
Kariyer \\
firsatlarını \\
bilme \\
durumu \\
\end{tabular}} & Evet & 12 & $40(32-75)$ & $37(28-42)$ & $8,5(6-11)$ & $87(71-116)$ \\
\hline & Hayır & 71 & $41(15-55)$ & $35(14-51)$ & $9(3-13)$ & $85(46-118)$ \\
\hline & $p$ & & 0,810 & 0,780 & 0,403 & 0,545 \\
\hline \multirow{7}{*}{$\begin{array}{l}\text { Hemşirelik } \\
\text { mesleğini } \\
\text { tercih etme } \\
\text { nedeni }\end{array}$} & \begin{tabular}{|l|} 
Aile \\
baskısı
\end{tabular} & 7 & $42(35-47)$ & $34(26-44)$ & $8(6-11)$ & $84(75-101)$ \\
\hline & $\begin{array}{l}\text { Iş bulma } \\
\text { kolaylığı }\end{array}$ & 32 & $40(26-75)$ & $35,5(28-50)$ & $9,5(7-13)$ & $84(68-116)$ \\
\hline & $\begin{array}{l}\text { Yüksek } \\
\text { gelir } \\
\text { beklentisi }\end{array}$ & 15 & $42(31-53)$ & $34(14-51)$ & $9(4-12)$ & $81(51-114)$ \\
\hline & \begin{tabular}{|l|} 
Üniversite \\
sınavına \\
tekrar \\
girmemek
\end{tabular} & 9 & $45(36-55)$ & $37(30-50)$ & $10(5-13)$ & $91(78-118)$ \\
\hline & \begin{tabular}{|l|} 
Üniversite \\
giriş \\
puanın bu \\
bölüme \\
yetmesi \\
\end{tabular} & 7 & $40(39-43)$ & $39(32-41)$ & $8(6-11)$ & 87 (78-91) \\
\hline & $\begin{array}{l}\text { Mesleği } \\
\text { sevmek }\end{array}$ & 13 & $40(15-50)$ & $33(27-45)$ & $8(3-11)$ & $82(46-100)$ \\
\hline & $p$ & & 0,109 & 0,912 & 0,144 & 0,288 \\
\hline \multirow{7}{*}{$\begin{array}{l}\text { Kariyer } \\
\text { planı } \\
\text { hedefleri }\end{array}$} & $\begin{array}{l}\text { Yönetici } \\
\text { hemşire } \\
\text { olmak }\end{array}$ & 19 & $40(33-53)$ & $37(14-45)$ & $8(4-11)$ & $86(51-105)$ \\
\hline & $\begin{array}{l}\text { Yüksek } \\
\text { lisans } \\
\text { yapmak }\end{array}$ & 22 & $42(15-75)$ & $33(28-50)$ & $10(7-12)$ & $86(54-116)$ \\
\hline & \begin{tabular}{|l} 
Özel \\
dallarda \\
eğitimi \\
almak \\
\end{tabular} & 19 & $41(31-53)$ & $40(30-51)$ & $9(5-12)$ & $88(70-114)$ \\
\hline & \begin{tabular}{|l|} 
Akademis- \\
yen olmak
\end{tabular} & 12 & $40(26-55)$ & $32,5(19-50)$ & $9,5(7-13)$ & $82(62-118)$ \\
\hline & $\begin{array}{l}\text { Meslek } \\
\text { değiştir- } \\
\text { mek }\end{array}$ & 6 & $36,5(33-54)$ & $37(35-40)$ & $9(8-13)$ & $82,5(79-104)$ \\
\hline & $\begin{array}{l}\text { Hemşire } \\
\text { olarak } \\
\text { çalışmak }\end{array}$ & 5 & $39(16-44)$ & $32(27-37)$ & $7(3-9)$ & $78(46-90)$ \\
\hline & $p$ & & 0,712 & 0,060 & 0,051 & 0,248 \\
\hline
\end{tabular}

Tanımlayıcı istatistikler medyan (minimum-maksimum) şeklinde verilmiştir. 


\section{Tartışma ve Sonuç}

Bu araştırma hemşirelik bölümü son sınıf öğrencilerinin kariyer planlama eğilimlerini değerlendirmek amacıyla yapılmıştır. Kariyer planlaması, bireysel kariyer planlama sürecini içeren ve yaşam boyu devam edecek bir süreçtir. Kariyer planlama sürecinde üç adım önemlidir. Bunlar; kendini tanıma, hedef belirleme ve planlamadır. ${ }^{15} \mathrm{Bu}$ üç sürecin tamamlanması ile kişi meslek seçimi yapar. Çalışmamıza katılan öğrencilerin çoğu mesleği gönüllü olarak seçtiklerini belirtmişlerdir. Literatürde Topbaş ve arkadaşları (2017) ile Çağlar ve arkadaşlarının (2017) araştırmalarında dördüncü sınıf öğrencilerinin yarısının, Karataş ve arkadaşlarının (2017) çalışmasında ise öğrencilerin çoğunluğunun gönüllü olarak hemşirelik mesleğini seçtiği gördürülmektedir. $\mathrm{Bu}$ çalışmanın sonuçları literatürle benzerlik göstermektedir. Ancak, bölümü isteyerek seçme durumları ile kariyer uyumu, kariyer iyimserliği ve algılanan bilgi arasında anlamlı bir fark bulunamamıştır. $\mathrm{Bu}$ veriler gönüllü olarak meslek seçimi ile kariyer planlamasının ilişkili olmadığını destekler niteliktedir. Bununla birlikte, literatür incelendiğinde cinsiyet faktörünün hemşirelik öğrencilerinin mesleki kariyerlerinin gelişiminde rol oynayabileceğini gösterilmektedir. Muldoon ve Reilly (2003) tarafından yapılan bir çalışmada öğrencilerin cinsiyetinin kariyer seçimlerini etkilediği ve erkeklerin kariyer planlamada öz yeterlilik algılarının kadınlara göre daha yüksek olduğu; Macintosh (2003) ve Martin ve Kipling (2006) tarafından yapılan çalışmalarda ise, katılımcılar hemşireliğin esas olarak kadınlara yönelik bir kariyer olduğu belirtmişlerdir. Literatürde erkek hemşirelerin liderlik pozisyonlarında kadın meslektaşlarına göre daha hızlı ilerlediğini gösteren bazı çalışmalara karşın, bazıları ise erkek hemşirelerin kariyerlerinin erken dönemlerinde kadınlara göre daha yüksek düzeyde sosyal strese maruz kaldıklarını ve mesleği bırakma olasılıklarının daha yüksek olduğunu göstermektedir. ${ }^{17,18}$ Araştırma sonuçlarına bakıldığında ise katılımcıların çoğunun kadın olduğu ve öğrencilerin cinsiyetlerine göre KARGEL alt boyut ölçek ve toplam puanları açısından istatistiksel olarak anlamlı bir farklılık olmadığı bulunmuştur. Yani kız ve erkek öğrenciler benzer kariyer uyumuna, kariyer iyimserliğine ve bilgi düzeyine sahiptir. Araştırmamızın sonuçları bu açıdan literatürle uyumlu değildir.

Diğer yandan bu çalışmada öğrenciler aile baskısı, yüksek gelir ve mesleğe olan ilgileri gibi kariyer seçimini etkileyen diğer faktörlerden de söz etmişlerdir. Yousef ve ark. (2017) araştırmalarında, hemşirelik öğrencilerinin kariyer seçimlerini etkileyen en önemli üç faktörün sırasıyla aile kararı, dini faktörler ve başkalarına yardım etme ve bakım yapma isteği olduğunu ifade ettiklerini belirtmişlerdir. Kertsen ve ark. ise çalışmalarında (1991) öğrencilerin hemşirelik mesleğini duygusal ihtiyaçlar, istihdam olanağı, finansal avantajlar ve bilime olan ilgileri nedeniyle seçtikleri sonucuna varmışlardır. Araştırma sonuçları literatürle benzerlik göstermektedir.

Hemşire öğrencilerin kariyer planlamasını etkileyen bir diğer faktör kariyer firsatlarının farkındalığını destekleyen bir yönetimin varlığıdır. Price ve ark. (2018) tarafindan yapılan çalışmada hemşirelik öğrencileri kariyer seçiminin başarısını, olumlu bir çalışma ortamına ve yöneticilerin desteğine bağlamışlardır. Hinds ve Harley (2001) ise öğrenci hemşirelerin uygulama alanında olumlu rol model olmayan hemşirelerle karşılaştıklarını belirtmişlerdir. Bu durum, yöneticilerin ve meslektaşların öğrencilerin kariyer seçimlerinde destekleyici rollerinin farkına varmalarının gerekliliğini daha çok ortaya çıkarmaktadır. Ancak bu çalışmada hemşirelik öğrencilerinin birçoğu kariyer planlarında kendileri için mevcut firsatların farkında olmadıklarını, çok azı ise yabancı dil eğitimi almış olmayı, bulundukları üniversitenin imajını, branşlara özel sertifika alabilmeyi kariyer firsatları olarak gördüklerini belirtmişlerdir. $\mathrm{Bu}$ durum eğitimcilerin kariyer firsatları konusunda yeterli danışmanlık yapmadıklarını gösteren önemli bir bulgu olarak değerlendirilebilir.

Hemşirelik öğrencilerinin kariyer yapma sürecini doğrudan etkileyen bir diğer önemli unsur ise algılanan kariyer engelleridir. Kariyer engelleri, bir kişinin kariyerine ilişkin şu anda var olduğuna veya gelecekte karşılaşılabileceğine inanılan engellerdir. ${ }^{26} \mathrm{Wu}$ ve ark. (2015) tarafından yapılan bir çalışmada hemşirelik bölümü öğrencilerinin algıladıkları kariyer engeli oranlarının orta düzeyde olduğu tespit edilmiştir. Bu çalışmada ise az sayıda öğrenci kariyer engelleri olduğunu ifade etmiştir. Öğrencilerin algıladıkları kariyer engelleri oranındaki azalmanın kurumda her yıl düzenli olarak verilen oryantasyon eğitimlerinin olumlu etkisinden etkilenmiş olabileceği düşünülmektedir.

Bu çalışmada, hemşirelik bölümü son sınıf öğrencilerinin ortalama KARGEL ölçek puanlarının yüksek düzeyde olduğu, ancak çok azının yabancı dil eğitimi almış olmak, bulundukları üniversitenin imajı ve branşlara özel sertifika alabilmek gibi kariyer firsatlarının farkında oldukları sonucuna ulaşılmıştır. Bu nedenle, öğrencilerin uyum sağlama yeteneklerini ve bilgilerini kariyer seçimlerinde firsata dönüştürmek için kariyer yönetim süreçleri eğitim kurumları tarafindan profesyonelce yönetilmelidir. Ayrıca hemşirelik öğretim elemanları, kariyer planlama kursları gibi hemşirelik öğrencilerinin kariyer geleceği farkındalıklarını arttırmaya ve hedeflerini belirlemeye yardımcı danışmanlık, mentorlük hizmeti yürütmeli ve stratejiler geliştirmelilerdir. Ayrıca, hemşirelik öğrencilerinin kariyer seçenekleri konusunda farkındalıklarını artırmak ve en uygun eğitim program yöntemlerini belirlemek için daha büyük örneklem gruplarıyla yapılmış araştırmalara ihtiyaç vardır. 


\section{H. Gökdere Çinar, ark.}

Etik Kurul Onay Bilgisi:

Onaylayan Kurul: Bursa Uludağ Üniversitesi Sağlık Bilimleri Araştırma ve Yayın Etik Kurulu

Onay Tarihi: 12 Şubat 2019

Karar No: 2019-03

Araștırmacı Katkı Beyanı: Fikir ve tasarım: H.G.C.; Veri toplama ve işleme: H.G.Ç., D.Y., M.A.; Analiz ve verilerin yorumlanması: D.Y.,B.A.,M.A.; Makalenin önemli bölümlerinin yazılması: H.G.Ç., D.Y

Destek ve Teşekkür Beyanı: Bu çalışmada finansal giderler araştırmacılar tarafından karsılanmıstır.

Çıkar Çatışması Beyanı: Makale yazarlarının çıkar çatışması beyanı yoktur.

\section{Kaynaklar}

1. Yavuz S. İsletmelerde kariyer yönetimi ve uygulamadan bir örnek (Yüksek Lisans Tezi). İstanbul: Marmara Üniversitesi 2006.

2. Taşlıyan M, Arı N, Duzman, B. İnsan kaynakları yönetiminde kariyer planlama ve kariyer yönetimi: İ̈BF Öğrencileri Üzerinde Bir Alan Araştırması. Organizasyon ve Yönetim Bilimleri Dergisi. 2011; 3: 241-231. ISSN: 1309 -8039

3. Kim SM., Kim YH., Kim HY. Hospital career management systems and their effects on the psychological state and career attitudes of nurses. Serv Bus. 2016; 10: 87-112. doi $10.1007 / \mathrm{s} 11628-014-0257-7$

4. Hoekstra HA. A Career roles model of career development. Journal of Vocational Behavior. 2011; 78:159-173. doi:10.1016/j.jvb.2010.09.016

5. Karadaş A, Duran S, Kaynak S. Hemşirelik öğrencilerinin kariyer planlamaya yönelik görüşlerinin belirlenmesi. SDÜ Sağlık Bilimleri Enstitüsü Dergisi. 2017; 8: 1-8. doi 10.22312/sdusbed.224956

6. Luzzo DA, Whirter EH. Sex and ethnic differences in the perception of educational and career-related barriers and levels of coping efficacy. Journal of Counseling \& Development. 2001; 79: 61-67. doi: 10.1002 / j.1556-6676.2001.tb01944.x

7. Kozak AM, Dalkıranoğlu T. Mezun öğrencilerin kariyer alg1lamaları: Anadolu Üniversitesi Örneği. Anadolu Üniversitesi Sosyal Bilimler Dergisi. 2013; 13: 41-52.

8. Jones BD, Paretti MC, Hein SF, Knott TW. An Analysis of motivation constructs with first-year engineering students: Relationships among expectancies, values, achievement, and career plans. Journal of Engineering Education. 2010; 319-306. doi:10.1002/j.2168-9830.2010.tb01066.x.

9. Laker DR, Laker R. The Five-year resume: a career planning exercise. Journal of Management Education. 2007; 31:128-142. doi:10.1177/1052562906290525

10. Beduwe C, Giret JF Mismatch of vocational graduates: What Penalty on French Labour Market? Journal of Vocational Behavior. 2011; 78: 68-79. doi: 10.1016 / j.jvb.2010.09.00

11. Cheng C, Yang L, Chen Y, Zou H, Su Y, Fan X. Attributions, future time perspective and career maturity in nursing undergraduates: correlational study design. BMC Medical Education. 2016; 16: 26. doi: 10.1186/s12909-016-0552-1
12. Arslan E, Özsoy S, Erkin Ö. Hemşirelik öğrencilerinin kariyer planlamaya yönelik görüşlerinin belirlenmesi. Ege Üniversitesi Hemșirelik Fakültesi Dergisi. 2013; 29: 1-9. doi: 10.22312/sdusbed.224956.

13. Kalafat T. Kariyer geleceği ölçeği (KARGEL): Türk örneklemi için psikometrik özelliklerinin incelenmesi. Türk Psikolojik Danışma ve Rehberlik Dergisi. 2012; 38:169- 179. ISSN: 13021370 .

14. Rottinghaus PJ, Borgen FH. The career futures inventory: a measure of career-related adaptability and optimism. Journal of Career Assessment. 2005; 13: 3-24. doi: $10.1177 / 1069072704270271$.

15. Göz F, Gürbüz K. Hemșirelikte kariyerinizi keşfedin. Atatürk Üniversitesi Hemşirelik Yüksekokulu Dergisi. 2005;8: 82-87.

16. Topbaş E, Görgen Ö, Şahin E, Çakmak N. Profesyonel hemşirelikte ilk adım kariyer planlaması. Uluslararası Hakemli Hemșirelik Araștırmaları Dergisi. 2017; 9: 99-116, doi: 10.17371/UHD.2017.3.9.

17. Çağlar S, Gözen D, Kerimoğlu GY, Kılıklı N, Ağar M. Hemşirelik fakültesi birinci ve dördüncü sinıf öğrencilerinin mezuniyet sonrası kariyer planlarının incelenmesi. F.N. Hemşirelik Dergisi. 2017; 25: 41-48. doi: 10.17672/fnhd.97895.

18. Abrahamsen B. Career development and masculinities among male nurses. NORA: Nordic Journal of Women's Studies. 2004; 12: 31-39. Doi:10.1080/08038740410005749.

19. Muldoon OT, Reilly J. Career choice in nursing students: gendered constructs as psychological barriers. Journal of Advanced Nursing. 2003; 43: 93-100. doi:10.1046/j.13652648.2003.02676.x

20. Macintosh J. Reworking professional nursing identity. Western Journal of Nursing Research. 2003; 25(6): 725-741. doi: 10.1177/0193945903252419.

21. Martin D, Kipling A. Factors shaping aboriginal nursing students' experiences. Nurse Education in Practice 2006; 6(6): 380-388. doi: 10.1016/j.nepr.2006.07.009.

22. Yousef S, Athamneh M, Masuadi E, Ahmad H, Loney T, Moselhy HF, Al -Maskari F, Elbarazi I. Association Between depression and factors affecting career choice among jordanian nursing students. Frontiers in Public Health. 2017; 5, 311. doi:10.3389/fpubh.2017.00311.

23. Kersten J, Bakewell K, Meyer D. Motivating Factors in a Student's Choice of Nursing as a Career. J Nurs Educ. 1991; 30:30-31. PMID: 1847407.

24. Price SL, Paynter M, Mcgillis LH, Reichert C. Intergenerational impact of management relations on nurse career satisfaction and patient care. The Journal of Nursing Administration. 2018; 48: 636-641. doi: 10.1097/NNA.0000000000000695.

25. Hinds R, Harley J. Exploring the experiences of beginning registered nurses entering the acute care setting. Contemporary Nurse. 2001; 10(1): 110-116. doi: 10.5172/conu.10.1-2.110.

26. Wu MC, Wu YP, Wan YP, Zeng Y, Tang XR, Wang LR. Effects of attribution retraining on the perceived career barriers of undergraduate nursing students. Int J Nurs Sci. 2015; 2: 99104. doi: 10.1016/j.ijnss.2015.01.009. 